\title{
The nurses' working process: the view of professors from a public university
}

\author{
Processo de trabalho do enfermeiro: visão de professores de uma universidade pública \\ Proceso de trabajo del enfermero: visión de profesores de una universidad pública
}

Luiza Hiromi Tanaka ${ }^{1}$ Maria Madalena Januário Leite ${ }^{2}$

\begin{abstract}
Goals: The study aimed to understand the working process of the nurse according to the perspective of professors of the Undergraduate Nursing Course at Universidade Federal de São Paulo. Methods: Exploratory study with a qualitative approach, having 14 professors as its subjects; the focus group technique was chosen for data collection, and the material was analyzed according to the method of content analysis. Results: The meaning of the nurses' working process comprised three categories: composition of the nurses' working process, differentials of the nurses' work when compared to other healthcare professionals and dichotomies of the nurses' working process in education. Conclusion: The meanings of this process were the group of the working processes: caring, managing, teaching and researching, whose working core is the process of caring. However, healthcare management was not evidenced by the focus group. The nurses' working process was considered complex and confusing.
\end{abstract}

Keywords: Nurses, male; Nurses, female; Nurse's role; Education; Professional practice

\section{RESUMO}

Objetivo: O estudo teve por objetivo compreender o processo de trabalho do enfermeiro na visão de professores do Curso de Graduação em Enfermagem da Universidade Federal de São Paulo. Métodos: Estudo exploratório de abordagem qualitativa, tendo como sujeitos 14 professores; a técnica de coleta de dados elegida foi o grupo focal e a análise do material foi fundamentada no método de análise de conteúdo. Resultados: O significado do processo de trabalho do enfermeiro compreendeu três categorias: composição do processo de trabalho do enfermeiro; diferencial do trabalho do enfermeiro frente a outros profissionais de saúde e dicotomias do processo de trabalho do enfermeiro na formação. Conclusão: Os significados desse processo foram: conjunto dos processos de trabalho - cuidar, administrar, ensinar e pesquisar, cujo núcleo do trabalho é o processo cuidar, entretanto, administrar o cuidado não foi evidenciado pelo grupo focal. O processo de trabalho do enfermeiro foi considerado complexo e confuso.

Descritores: Enfermeiros; Enfermeira; Papel do profissional de enfermagem; Ensino; Prática profissional

\author{
RESUMEN \\ Objetivo: En este estudio se tuvo como objetivo comprender el proceso de trabajo del enfermero en la visión de profesores del Pregrado en \\ Enfermería de la Universidad Federal de Sao Paulo. Métodos: Se trata de un estudio exploratorio con abordaje cualitativo, teniendo como \\ sujetos a 14 profesores; la técnica de recolección de datos elegida fue el grupo focal y el análisis del material estuvo fundamentado en el \\ método de análisis de contenido. Resultados: El significado del proceso de trabajo del enfermero comprendió tres categorías: composición \\ del proceso de trabajo del enfermero; diferencial del trabajo del enfermero frente a otros profesionales de salud y dicotomías del proceso de \\ trabajo del enfermero en la formación. Conclusión: Los significados de ese proceso fueron: conjunto de los procesos de trabajo - cuidar, \\ administrar, enseñar e investigar-, cuyo núcleo de trabajo es el proceso de cuidar, entre tanto, administrar el cuidado no fue evidenciado por \\ el grupo focal. El proceso de trabajo del enfermero fue considerado complejo y confuso. \\ Descriptores: Enfermeros; Enfermeras; Rol de la enfermera; Formación; Práctica profesional \\ * Part of this work was extracted from the Doctoral Dissertation presented to Escola de Enfermagem, Universidade de São Paulo - USP - São Paulo (SP), \\ Brazil. \\ ${ }^{1}$ RN, Escola de Enfermagem, Universidade de São Paulo - USP - São Paulo (SP), Brasil; Professor at the Nursing Department of Universidade Federal de \\ São Paulo - UNIFESP - São Paulo (SP), Brazil. \\ ${ }^{2}$ Free lecturer, Professor at Departamento de Orientação Profissional, Escola de Enfermagem, Universidade de São Paulo - USP - São Paulo (SP), Brażil.
}




\section{INTRODUCTION}

This article is part of the Doctoral dissertation that approaches the nurses' working process as the focus of the undergraduate student's education, in the perspective of the professors.

The Commission of Studies in Nursing Curricula Comissão de Estudos em Currículos de Enfermagem (CECE) of the Nursing Department at Universidade Federal de São Paulo (UNIFESP) had been working with the professors of the Nursing Undergraduate Courses, selecting, as one of the main goals, the proposition of a guiding axis for the education of the nurses.

In 2003, as a representing member of the course Management Applied to Nursing at CECE, there was an awakening of the attention to knowing the nuclear work of the nurse in the education of our undergraduates. The students, especially those in the last semester, when accompanied in their internship programs, asked about the difference of the nurses' work in the nursing team, as well as in the multiprofessional work, and the dichotomy of caring and managing.

As for professional education, the undergraduates say that there was a strong characteristic: direct care to the patient. This characteristic was perceived due to the preference for areas such as intensive care and emergency. At the same time, some undergraduates have been observed to choose the Public Health area, and others set their goal as the teaching and researching areas, right after graduation, by believing that the valuation of the nurses' work happens in these areas.

Regarding the professors, in a meeting with the representatives of courses of the third semester, the course "Management III" was mentioned to provide the opportunity for the students to know the managerial role of the nurse, since the nurse's role was already being taught since the first semester, along with other courses.

The professors of the Management course mentioned that the management of healthcare and the working unit is central to the nurse's profession, and that the education of the undergraduate should approach the interaction of healthcare with management.

In this context, the following questions arose: In which working process does the education of the Nursing undergraduates predominate? What would be the meaning of the nurses' working process for the professors?

A pedagogue from the Nursing Department, who was also a coordinator of CECE in the 1998-2004 period, described the professors' questions while the work was being developed: Which object is being referred? Assisting? Caring? Teaching? Investigating? Managing? All of them or just some of them? In this order or in another? Who or what establishes this order? ${ }^{(1)}$

In face of the possibility of enlarging the discussion about the questions of the nurses' working process in the education of undergraduates, the study was initiated with the goal of understanding the nurses' working process and its elements, according to the perspective of the professors of the courses that comprise the Nursing undergraduate at UNIFESP.

To understand the nursing work, it is necessary to understand the working process and how it is inserted in the healthcare work, because nursing is one of the services provided to health, and also a part of the tertiary sector of the Brazilian economy. Therefore, it does not produce goods to be stocked and sold, but services that are consumed at the moment of their production, at the moment of the provision of healthcare, both individually and collectively. However, it is different from other types of work of the same tertiary sector of service provision, since it deals with a human object: the users, the social groups and the populations that bring demands related to the health-disease process, expressed as needs or healthcare problems ${ }^{(2)}$.

Marx broke down the working process in three elements: the object of work, which an activity incides over and which will be transformed during the process, becoming a product; the means and instruments of work; and the activity designated to an end, the work itself, which is organized thematically ${ }^{(3)}$.

The nursing working process, in particular, is a network, or a group of subprocesses, that are named caring, managing, researching and teaching. Each of these can be taken as an individual process with its own elements (object, means/instruments and activity), and may or may not coexist at a given moment or institution. Among these many processes, the agents, i.e., the nursing workers, are inserted in a heterogeneous, hierarchical way, expressing the technical and social division of the nursing work ${ }^{(4)}$.

Studies show the social and technical division of the nursing work, and the secondary level nursing personnel are mostly the ones made responsible for the care activities while the registered nurse is assigned with the managerial actions covering health care and the unit. The work of providing care service and administration is the outcome of a historical and social result of $19^{\text {th }}$ century health practice in England, with Florence Nightingale ${ }^{(1,5-6)}$.

Regarding the organization and execution of healthcare for the sick, there are two different categories: the ladynurses and the nurses. Lady-nurses were considerer special students, whose education included classes about management and leadership, plus two years of practice, and the nurses, considered as common students, who were not prepared for management, but for the execution of patient $\operatorname{care}^{(5-6)}$.

In this context, the complexity of the nurse's care is more 
comprehensive, and some authors have stressed the specificity of the nurse's work and the healthcare management, which integrates caring and management ${ }^{(1-7-9)}$.

Therefore, during the education of the undergraduates, it is necessary for them to acquire the professional work from their practices, from the sum of the thoughts of the professors and in the knowledge obtained in each course.

\section{METHODS}

This is an exploratory study with a qualitative approach, developed in the Nursing department at UNIFESP, a public institution located in the city of São Paulo. Every year 88 students enroll in the Nursing undergraduate course, which lasts four years. The course has a full-time schedule, totaling 5021 hours.

The coordination of this course is part of the Curricular Commission, responsible for the administrative and assistance issues related to the undergraduates. This Commission is supported by CECE, which deals with the issues of the political-pedagogical project of the Nursing undergraduate course. The CECE members are represented by professors of the university and students of all the semesters of the course.

The subjects in this study were 14 professors of the Nursing undergraduate course at UNIFESP, in the following courses: Pediatrics, Obstetrics, Adult Healthcare and Collective Health. The professor of the Management course was absent.

The first contact with the professors, inviting them to participate in the study, happened through an e-mail sent to each of the professors who were part of the Nursing department staff, working with the undergraduates in theory and in the internship periods, and who had been working for UNIFESP at the Nursing undergraduate course for at least five years. As the answers came, confirming their participation, the best date and time were registered for each of them, until a group with 15 professors could be formed. After reaching this mark, the period of invitation was finished.

The technique used for data collection was the Focus Group, whose application is indicated for studying the representations present in a given social group. In a certain way, it simulates spontaneous conversations that link the representations to the everyday routine ${ }^{(10)}$. Therefore, the choice of this methodological strategy for this study is justified because it makes it possible to gather professors from different courses together, promoting critical reflections about the nurses' working process. The initial question of the meeting was: What is the meaning of the nurses' working process? It is worth noting that in the four subsequent meetings, the theme discussed was, respectively, each nursing working process: caring, managing, teaching and researching. The discussion, shared with the professors through the focus group about the nurses' working process brought different aspects, and the questions of the students were made evident as doubts of the professors themselves.

The research project was approved by the Review Board of UNIFESP (process \#0331/07), and the subjects were informed about the objectives of the study and the data collection technique. They signed the term of consent, agreeing to have the session recorded before the beginning of the study. The session lasted for two hours, and a validation of the meeting was performed before the end, using a synthesis of the points discussed.

The group coordinator was the researcher herself, and the group observer was an organizational psychologist. The speeches were written down, synthesized and analyzed, highlighting their essential points, as well as her perceptions in relation to the subjects and the group.

The method used to analyze the speeches of the Focus Group was content analysis, which, in general terms, relates the semantic structures with the sociological structures of the speeches. The thematic analysis technique was used, trying to meet the manifested and latent meanings in the qualitative material. Such technique consists in discovering the meaning cores that compose a type of communication whose presence or frequency means or reveals something important for the subjects and for the analytical objective of the study ${ }^{(10)}$.

The three stages used in the thematic analysis were: pre-analysis, consisting of a floating reading and organization of the material obtained from the focus group, which was transcribed by the researchers and validated by the research subjects. The subjects received the following pseudonyms: Quaresmeira, Acácia, Figueira, Cajueiro, Salgueiro, Jacarandá, Carvalho, Amoreira, Eucalipto, Oliveira, Cedro, Cipreste, Manacá and Mangueira; The exploration of material, which implied in classifying and aggregating the data and choosing the categories that commanded the specification of the themes; and the treatment of results, inference and interpretation. It consisted in the presentation of the synthesis of the categories and the interpretation in the perspective of the reference about the nurses' working process and the nurses themselves.

\section{RESULTS}

Regarding the identification of the study participants, they were all female, with four holding a Master's Degree and ten holding a Doctoral Degree. Nine had between 10 to 20 years of teaching experience, and five had from 21 to 30 years of teaching experience.

Three central thematic categories were obtained from the subjects' speeches, as follows: 
Composition of the nurses' working process: The meaning cores identified were: "they compose the four processes: caring, managing, educating and researching", "caring is the essence of the nurses' work", and "it is very confusing and complex to define the nurses' working process and its elements".

The subjects agreed about the nurses' working process being composed of the processes: caring, managing, educating and researching, and that there is no dichotomy among them. They also highlighted that the professor must educate the student to care, and that the other processes (managing, educating and researching) revolve around it. There was some confusion in defining the nurses' working process, and also, how the organization of the nurses' work happens.

Regarding the nurses' working object, one of the subjects said: "(...) the nurses' working process is the individual, family and community care" (Mangueira).

Regarding the result or the goal of the nurse's work, the subjects mentioned that it is the promotion, protection, rehabilitation and recovery of health.

Carvalho manifested that the nurses' working process is very complex, and that it involves assistance, research and teaching. And still, that "the nurses' working process is very confusing. We beat around the bush and do not define it".

It was evident that naming and differentiating the working processes and their elements were the difficulties perceived by the subjects, especially regarding the nurse's core work, and its working object. However, there was a consensus that the essence of the nurses' working process is caring. "(...) the working process is very similar to the process of caring. It seems like all of us have something in common... very common... as a working process for us, professors." (Figueira)

The nurses' working differential in face of other healthcare professionals: The meaning cores highlighted in this category were: "caring is not one of the nurses' prerogatives" and "the nurses' work is integrated with the other healthcare professionals".

One of the subjects expressed the concern about the nurses' working differential in this speech: "I have the impression that this discussion about caring, teaching and researching responds to the working process of any healthcare professional. (...) So, what came to my mind is, what is the differential of the working process of the other professionals, not the nurses. And I can't see any difference there. Because caring itself is not one of the nurses' prerogatives. (...) because, when it comes to the nurses' working process, as a professional, it's not specific for me who the nurse is".

The nurse's specific care was questioned by Mangueira, as shown in the following speech: "the issue of caring, I think it's so confusing in everyone's minds... we, as teachers. I'll give an example that I've gone through when I was a companion to a patient within the hospital. In the geriatrics wing, the speech pathologist was the one who taught how to place the tube and how to administer it. Aspirating, is it part of the nurse's job? I don't know any more! So, since we don't know what type of care is our responsibility, these things start to happen. When we don't have it defined, we don't transform that action into something that's ours."

Cipreste argued that the nurses' working process is the care, in the aspect of integrality and multiprofessionalism.

Dichotomies of the nurses' working process in education - The meaning cores identified were: caring and managing, the ideal and the real, public health and the hospital.

There was a reflection by one of the subjects regarding what we are teaching and what the job market is showing our students.

Jacarandá made a statement about the issue of the job market, which requires the nurse more managing than caring. Figueira named this external condition as parallel teaching, questioning whether we teach the working process, since what we teach seems not to meet the demand, or we are not giving the nurses enough subsidies to help them cope not only with the market, but also with their original motivation to become a nurse.

Manacá highlighted that the working process, in the market's perspective, expects the nurse to be that which the university does not always believe that the nurse has to be. As an example, Manacá reported her reality with the students. "T really stress the need of the nurses to place themselves as political beings, because I believe that, as political beings, they can be agents of their own transformation and achieve social recognition. However, the nurses are professionals who are expected to have the 'band' - they need to know how to perform certain techniques. The market and/or the users expect the nurses to be effective when performing these techniques. They are not expected to be critical, and the absence of critical thinking may lead to alienated actions. And now, as nurses, they have a specificity which, currently, I believe it's their technique. I think that nursing care is based on technique."

As for the dichotomy between public health and the hospital, a perception is made evident, as well as a certain prejudice of not caring much for public health, perceived by the focus group subjects. "They are dichotomic, yes, and there is the prejudice and the student learns the prejudice." (Manacá). "How can students learn to see the individual as a whole if there is a dichotomy between public health and the hospital in our department?" (Cedro). In face of this problem, Figueira said that it is very confusing for the students, until they learn the working process and caring in this amplitude.

\section{DISCUSSION}

The make-up of the nurses' working process is mingled with the healthcare and nursing working processes - caring, managing, teaching and researching, as well as in relation to its elements: working objects, means and goals.

This situation is natural because the nursing practices become more complex as they are acquired, connected 
to the healthcare practices and other social practices, and have the peculiar character of being constituted, effectively, as types of work inserted in processes of service production. The working process can only be acquired as such if all its components are considered, simultaneously and articulately. And still, that a given working process does not occur by itself, but as part of a network of reciprocal processes ${ }^{(7)}$.

As for the elements that compose the working processes as a process of transformation, it is important to show that they happen in function of the working activity, performed with the productive consumption of the workforce, and also with the intermediation of instruments that the agents insert between themselves and the object, to direct the activity to a certain goal. Therefore, the working process can only be understood as such if all its elements are considered simultaneously and articulately ${ }^{(7)}$.

It was not possible to discuss in-depth the elements that make up the nurse's work in this study. Overall, the focus group noted that the nurses' professional healthcare was the working object of this professional.

A literature review about the specificities of the elements that make up the nursing working processes resulted in two perspectives for the nurses' working object, nursing healthcare and healthcare management ${ }^{(11)}$. Both objects express the intrinsic double dimension of the nurses' working process - healthcare and managerial work.

Traditionally, in the composition of the working process of the nursing field, caring relates the activities developed directly with the clientele. It is defined as the main activity, and the others would be indirect activities, i.e., preparation and support for the first ${ }^{(12)}$.

Resolution 1,721/94 of the Ministry of Education defines the profile of the nurses in the perspective of a generalist education, being competent to develop their activities in four fundamental areas, these being caring, management, teaching and research. The nurses' educational process must be directed to caring for the human beings in their evolutional cycle, comprehending promotion, protection and recovery of health ${ }^{(13)}$.

It also seeks to correct the preventive/curative dichotomy, proposing the development of disciplines focusing on individual and collective healthcare, with practice/internship programs in both the hospital area and on the basic network of healthcare services. This proposal shows, as its reference the critical view of the conditions of life and the epidemiologic profile of the population, considering the demand of the healthcare services and the political guidelines for the healthcare sector ${ }^{(14)}$.

In reference to individual and collective health, the clinical model aims at recovering the individual body. Therefore, in this clinical healthcare model, nursing is part of the medical activity; its action is an instrument that will care for, or will oversee the care of the sick body ${ }^{(15)}$.
As a collective type of work, the nursing actions are executed along with other activities performed by distinct agents of the multiprofessional healthcare team. In this articulation, each specialized activity is the means that will allow the healthcare work to be performed ${ }^{(2)}$.

Regarding the differential of the nurses' work, studies performed about the working process evidence caring as the essence of the nursing activity, whereas the working process, healthcare and unit management caused the specificity of the nurse, both in the hospital environment and in the basic healthcare units. The nurses recognize and express the existence of intense conflicts and stress between healthcare management, their private and predominant action, and execution of healthcare, which is mostly under the responsibility of the nursing auxiliaries $^{(11,16-17)}$. In this aspect, the focus group subjects did not note the relation of the execution of direct care with the nursing auxiliaries and/or technicians, only with the nurses themselves.

Therefore, for the subjects, caring was considered the main working process in teaching to feature the nurse that we intend to educate, while managing, as the nurses' working essence, is shown as a necessity of the job market.

For this thematic, the discussion happened around the nurse inserted with the other healthcare professionals, not with the healthcare team. In addition, the nurses' working process of managing was not conflicting, placing this process as a means to care, as well as teaching and researching, emphasizing that direct care is the core activity of the nurse.

Regarding this evidence from the focus group subjects, it corroborates with the students' verbalizations, when it is mentioned that the nurses' working process emphasized by our course is the working process of caring, focused on direct care. When the students have to take the Management course, they suffer the dichotomy of direct and indirect care, which is then mixed up with caring for the patient, healthcare and working unit management.

The differential that will delimit the management performed by the nurses as truly being healthcare management will be their attitude in face of how this activity is developed. It is necessary to consider how these professionals become involved in their activities, which knowledge they use, and, especially to whom or what they have to answer to when using $\mathrm{it}^{(8)}$.

The healthcare practices must be supported by an innovative, differentiated utilization of the many types of technologies, not only those belonging to the technological models used to develop the scientific administration and the clinical healthcare model. Healthcare management demands the healthcare professionals, particularly the nurses, a view that integrates and welcomes the differentiated values and logics present in the needs of the users, not manifested or acknowledged until some time ago ${ }^{(8)}$. 
As for the dichotomy between theory and practice, between what is taught, what the nurses have been (un)prepared to do and what they do, there is also a historical crisis of professional identity ${ }^{(18)}$.

In several schools, what seems to have been built or idealized is the work of the nurse as something ready and finished, capable of fitting into a perfect and finished structure, where the nurse performs direct care for the patient with quality. However, after graduation, the nurses have to face the demands of the job market. Probably they had not been prepared for that, due to the type of education received. This type of education still has not been adequately and systematically developed in the daily routine $^{(19)}$, thus becoming a dichotomy.

From the literature review about the nurses' working process, teaching occurred, mainly, in the healthcare education and that of the nursing team to qualify the staff to care. However, the research working process, as a necessity of the nurses' professional education, was not relevant.

Therefore, starting from this study, we will be able to advance, covering other themes of this focus group, and investigate in-depth the meaning of each working process of the nurses.

\section{REFERENCES}

1. De Santi MC, Ohl RIB, Pereira AL, Fustinoni SM. A vivência das mudanças no ensino de graduação em enfermagem na Universidade Federal de São Paulo. Ácta Paul Enferm. 1998; 11(N Esp): 14-6.

2. Felli VEA, Peduzzi M. O trabalho gerencial em enfermagem. In: Kurcgant P, coordenadora. Gerenciamento em enfermagem. Rio de Janeiro: Guanabara Koogan; 2005. p.113.

3. Marx K. O capital: crítica da economia política. 3a ed São Paulo: Nova Cultural; 1988. v.1. cap. 5.

4. Felli VEA. O desgaste do trabalhador de enfermagem: relação trabalho de enfermagem e saúde do trabalhador [tese]. São Paulo: Escola de Enfermagem da Universidade de São Paulo; 1996.

5. Almeida MCP, Rocha JSY. O saber de enfermagem e sua dimensão prática. São Paulo: Cortez; 1986.

6. Ribas-Gomes EL, Anselmi ML, Mishima SM, Villa TCS, Pinto IC, Almeida MCP. Dimensão histórica da gênese e incorporação do saber administrativo na enfermagem. In: Almeida MCP, Rocha SMM, organizadoras. O trabalho de enfermagem. São Paulo: Cortez; 1997. p. 229-50.

7. Peduzzi M; Laços, compromissos e contradições existentes nas relações de trabalho da enfermagem. In: $53^{\circ}$. Congresso Brasileiro de Enfermagem. Curitiba, 2001. Anais. Curitiba: Aben; 2001. [Seção PR].

8. Rossi FR, Silva MAD. Fundamentos para processos gerenciais na prática do cuidado. Rev Esc Enferm USP. 2005; 39(4):460-8.

9. Hausmann M. Análise do processo de trabalho gerencial do enfermeiro em um hospital privado no município de São Paulo: possibilidades para o gerenciamento do cuidado [dissertação ]. São Paulo: Escola de Enfermagem da Universidade de São Paulo; 2006.

10. Minayo MCS. O desafio do conhecimento: pesquisa qualitativa

\section{FINAL CONSIDERATIONS}

This study responded to the proposed goal, and the execution of the focus group was highly satisfactory, and considered a very significant learning opportunity for the group.

It was observed that, if there were no professors from the Collective Healthcare area in the group, the educational perspective would be focused on the hospital environment, in its technical and individual mode of caring. The lack of unity about who are the nurses that we want to educate was observed, in face of the meaning of the nurses' working process.

Verbalizations from undergraduate students in relation to the questions presented about the differential of the nurses' work in the nursing team, as well as the dichotomy of caring and managing and the strong characteristic of our education, which is the direct care to the patient, were understood in the multiprofessional activity. However, they deserved to be discussed more in-depth, as well as the elements that compose the nurses' working processes that were not highlighted in this study, especially the object as part of the nurses' work.

em saúde. 8a ed. São Paulo: Hucitec; 2004

11. Peduzzi M, Anselmi ML. O processo de trabalho de enfermagem: a cisão entre planejamento e execução do cuidado. Rev Bras Enferm. 2002; 55(4):392-8.

12. Saupe R. Ação e reflexão na formação do enfermeiro através dos tempos. In: Saupe R, organizadora. Educação em enfermagem: da realidade construída à possibilidade em construção. Florianópolis: Editora da UFSC; 1998.

13. Brasil. Ministério da Educação e Cultura. Portaria no 1721 , de 15 de dezembro de 1994. Fixa os mínimos de conteúdo e duração do Curso de Graduação em Enfermagem. Diário Oficial da União. Brasília (DF), 16 de dezembro de 1994, seção 1, n. 238, p. 19.801-19.802.

14. Fernandes JD, Lopes RLM. Nós, a enfermagem e a academia. Salvador: Etera; 2002.

15. Castellanos BEP, Rodrigues AM, Almeida MCP, Rosa MTL, Mendes SASA; Desafios da enfermagem para os anos 90. In: $41^{\circ}$. Congresso Brasileiro de Enfermagem. Florianópolis, 1989. Anais. Florianópolis: Aben; 1989. [Seção SC].

16. Leopardi MT, Gelbcke FL, Ramos FRS. Cuidado: objeto de trabalho ou objeto epistemológico da enfermagem? Texto \& Contexto Enferm. 2001; 10(1):32-49.

17. Villa TCS, Mishima SM, Rocha SMM. Enfermagem nos serviços de saúde pública do Estado de São Paulo. In: Almeida MCP, Rocha SMM, organizadoras. O trabalho de enfermagem. São Paulo: Cortez; 1997. p.27-60

18. Lunardi Filho WD, Lunardi VL. Uma nova abordagem no ensino de enfermagem e de administração em enfermagem como estratégia de (re)orientação da prática profissional do enfermeiro. Texto \& Contexto Enferm. 1996; 5(2):20-34.

19. Lunardi Filho WD. O mito da subalternidade do trabalho da enfermagem à medicina. Pelotas: Editora Universitária: UFPel; 2000. 